\title{
Access to Finance and Agency: An Overview of the Constraints to Female-Run Enterprises
}

\section{Farah Said ${ }^{*}$}

\begin{abstract}
A large proportion of women in Pakistan engage in home-based production rather than wage employment in the public space to generate an income. This article provides an overview of the literature on the role of access to finance and women's decision-making power (at the household level) on the likelihood of business creation and growth by women. The literature shows that finance has little impact on business and household outcomes; this suggests that other constraints are at play when it comes to women setting up an enterprise or making business decisions. This overview shows how self-control - risk aversion and present biasedness - can inhibit business investment. Household members may also 'capture' a woman's financial resources, including business loans or savings, and put them to unproductive use. Further, social and cultural norms may dictate whether setting up an enterprise is seen as an 'appropriate' activity for women. Against the backdrop of several government and private initiatives to promote enterprise, exploring these issues provides us with important insights into how female-run businesses can be encouraged and supported.
\end{abstract}

Keywords: Entrepreneurship, microfinance, credit constraints, household decision-making, norms.

JEL classification: D14, J16, 012, P34, P36.

\section{Introduction}

Pakistan has had a long-standing low labor participation rate: the national rate of active labor participation stands at a little under 46 percent. ${ }^{1}$ Such low indicators are particularly troubling for a developing country trying to combat poverty and inequality. Labor participation is disproportionately low among women: at 22 percent, the female

\footnotetext{
* Assistant Professor and Research Fellow, Centre for Research in Economics and Business, Lahore School of Economics.

${ }^{1}$ All figures are from the Labor Force Survey for 2013/14 (Pakistan Bureau of Statistics, 2015). It is worth noting that the survey uses a liberal definition of 'currently active': it includes all employed and unemployed individuals aged 10 and above, who are either looking for work or are involved in paid employment or the trade of goods and services in the market for own consumption or barter.
} 
participation rate is one third that of the male participation rate. The disparity between male and female participation is even greater in paid employment (13 percent for women versus 43 percent for men) and formal microenterprises (19 percent for women versus 41 percent for men). In the informal sector, the gender ratio is more equitable, albeit low, at 38 percent for women and 42 percent for men. According to data from the Global Entrepreneurship Monitor, there are 17 male entrepreneurs to every female entrepreneur at the startup stage (Figure 1). This gender ratio is lower than in other developing countries in South Asia and Africa.

Figure 1: Total early-stage entrepreneurial activity, by gender

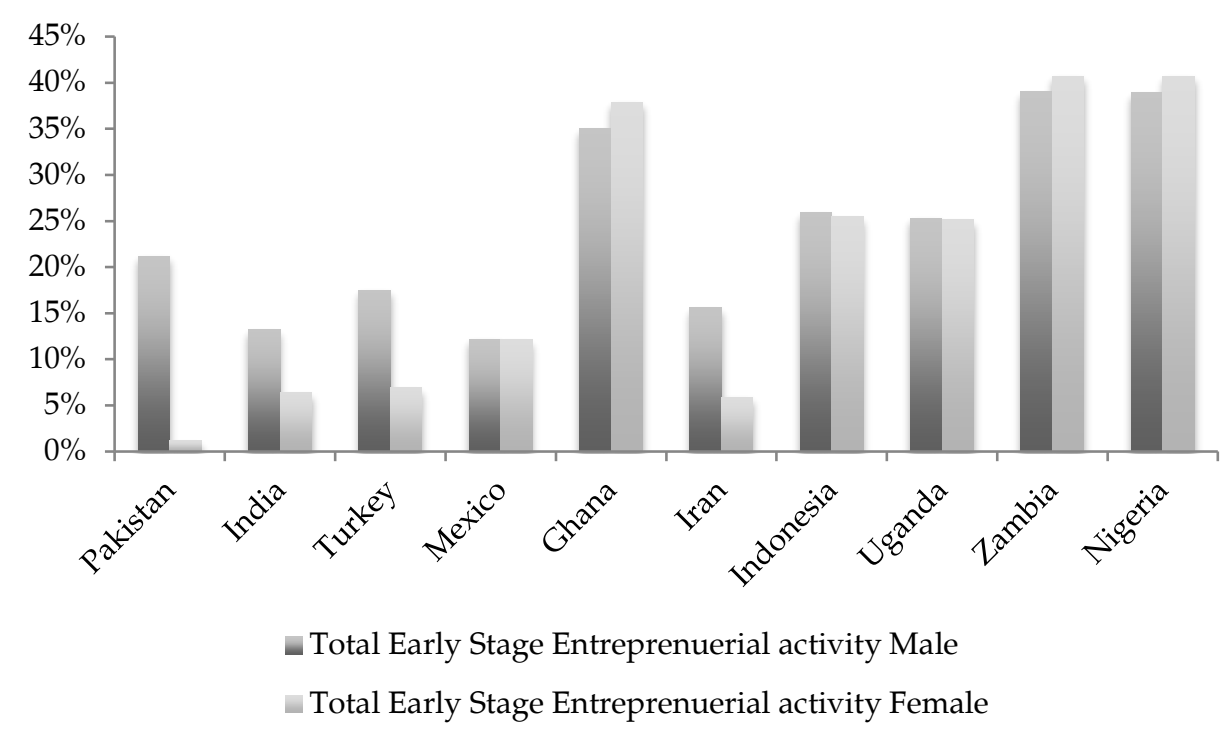

Source: Global Entrepreneurship Monitor 2012/13, retrieved from http://www.gemconsortium.org/data/key-indicators

Should we be concerned about this gender disparity? The answer is, undisputedly, yes. The literature shows that the welfare impact of a cash infusion in the household will be very different depending on the recipient of the inflow. Household welfare, as measured by child health, nutrition and education, tends to be higher when cash is allocated by a woman as opposed to a man (see Yoong, Rabinovich \& Diepeveen, 2012, for a literature review). Of course, one can argue that economic empowerment has a value per se that ought not to be concentrated in only the male members of the household. That we should be concerned about gender disparity is not disputed. What is less clear is what might explain the gender gap in economic activity. 
Part of this gap can be explained by the returns to education. Male and female educational attainment is vastly different, particularly beyond the primary level. However, a plausible reason for this gap (including that in educational attainment) may also be the difference in access and opportunity. Social and cultural norms affect the role of a woman in society, often delineating her as a caregiver - any paid employment she seeks outside the home must not then interfere with her responsibilities at home. This limits her to finding employment closer to home. One argument is that society and the institution of purdah frowns on - if not disallows outright - the woman from working outside the home at all. This may explain why more women engage in home-based production rather than wage employment in the public space to earn an income.

Other than access to financial and technical resources, female-run enterprises in Pakistan are, therefore, limited by sociocultural concerns. Notwithstanding government grants and policies, the needs of microentrepreneurs among the disadvantaged in Pakistan are met largely by the microfinance sector. While not catering to the ultra-poor, microfinance organizations provide small, short-term loans to those just above the poverty line, who are unbanked by the traditional financial sector. A detailed exploration of this issue, including a robust empirical investigation, will be directly useful to policymakers and practitioners.

The role of enterprise in economic growth has long been recognized (see Knight, 1921; Schumpeter, 1942; Baumol, 1968) and its importance for women as an acceptable form of income generation makes it all the more pertinent to improving welfare and growth. The Government of Pakistan has already shown keen interest in encouraging entrepreneurship, a testament to which is the Prime Minister's Youth Business Loan Program whereby young people (aged 21 to 45 ) are provided subsidized financing. ${ }^{2}$ The program specifically requires that half the funds be disbursed to female borrowers. Against this backdrop, the findings of such a study will be of direct interest to the government as it decides how best to extend credit to these entrepreneurs.

Section 2 provides an overview of the microfinance sector in Pakistan. Section 3 gives a detailed literature review on microenterprise growth and creation in general and on female-run businesses in particular. It also discusses studies that have attempted to measure household dynamics and social norms. Section 4 concludes, with brief suggestions for future research.

\footnotetext{
${ }^{2}$ Prime Minister's Youth Program (http://youth.pmo.gov.pk).
} 


\section{Microfinance for Women in Pakistan: An Overview}

Typical credit products offered by commercial banks do not cater to micro-entrepreneurs. Muhammad Younis revolutionized the field of credit in the 1990s when he introduced financial products targeting the poorest men and women in Bangladesh - a segment that was typically unbanked, with limited or no access to traditional finance provided by commercial banks. Since then, this model of finance has been adopted worldwide, with regional and cultural variations. However, such loans are typically uncollateralized, small, short-term and offered at higher interest rates. Default is minimized by various checks and balances, joint liability and/or guarantee systems. Clients tend to be from marginalized segments and are often women. Arguably, given women's limited mobility, fraud and default are lower. In addition, access to financial resources has the potential to improve the welfare of the recipient as well as the household.

Microcredit was first introduced by the Aga Khan Rural Support Program and the Orangi Pilot Project in the early 1980s. The microfinance sector in Pakistan is one of the more developed sectors in the region (Economist Intelligence Unit, 2012) in terms of market capacity and the commitment shown by its regulators, but it lags behind its neighbors in terms of adoption (Villasenor, 2016). Outreach is unevenly spread, with most microfinance institutions providing access to markets in Punjab and Sindh and very little presence in most of Balochistan. With an estimated 1.7 million active borrowers and a loan portfolio of more than US\$460 million, ${ }^{3}$ the sector has institutional support from the State Bank of Pakistan ${ }^{4}$ and boasts a robust growth rate.

However, the gender ratio is less favorable to women than in other countries (Figure 2). While 94 and 91 percent of borrowers in India and Bangladesh, respectively, are women, the corresponding ratio for Pakistan is only 59 percent (Safavian \& Haq, 2013). Why does Pakistan have a lower proportion of women borrowers? Is it for lack of demand among women or are microfinance institutions unwilling to lend to them? Safavian and Haq (2013) estimate that 90 percent of women require permission from their husbands to apply for a loan, while two thirds of women in rural areas and about a third in urban areas report being able to use the loan for their own purposes. The remainder of borrowers report that the loan was used by male family members.

\footnotetext{
${ }^{3}$ Microfinance Information Exchange (www.mix.org).

4 This includes the Microfinance Institutions Ordinance 2001, the Prudential Regulations for Microfinance Banks and the central bank's strategy for expanding microfinance outreach.
} 


\section{Figure 2: Country ranking, by microfinance outreach to women}

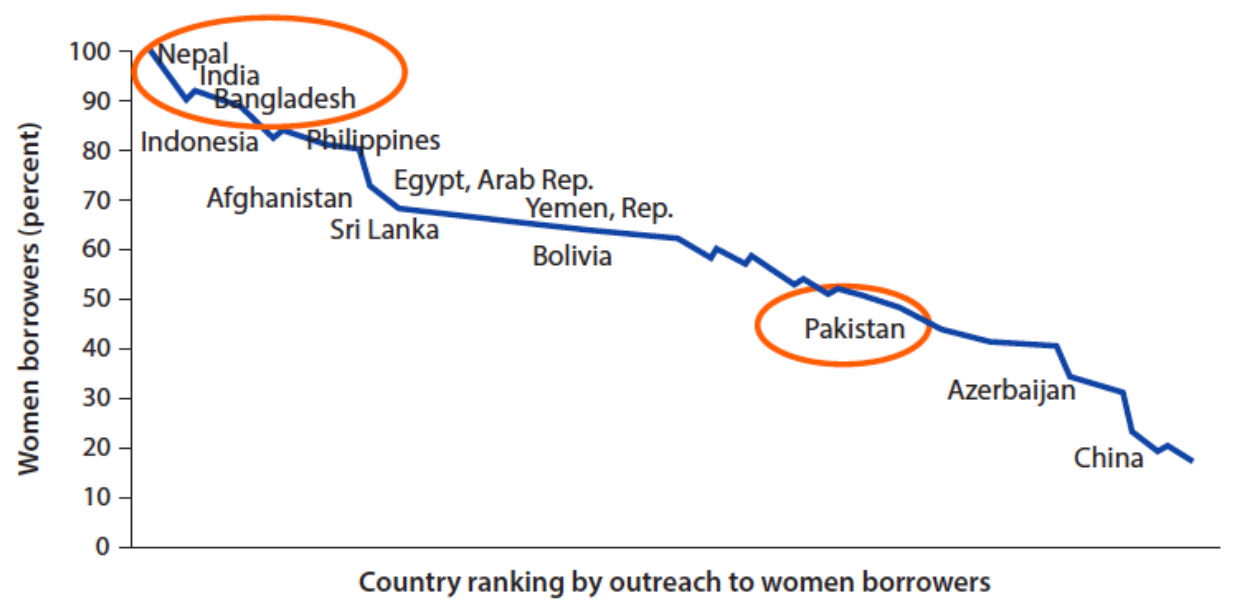

Source: Microfinance Information Exchange (2010, cited in Safavian \& Haq, 2013).

Further, 60 percent of women report having to persuade their husbands to pay back the loan. On the supply side, there is no evidence to suggest that microfinance institutions discriminate against women borrowers. On the contrary, some NGO-based microfinance institutions focus explicitly on women clients, e.g., the Kashf Foundation and Aga Khan Rural Support Program - two of the largest and oldest microfinance providers in Pakistan. Others have gender-neutral policies that do not discourage women borrowers: women constitute 70 and 20 percent of the borrowers of the National Rural Support Program and Khushali Bank, respectively. ${ }^{5}$

A few quasi-experimental academic studies ${ }^{6}$ have looked at the impact of access to finance on both men and women in Pakistan. Using propensity score matching, Asim (2009) finds that participation in microcredit programs does not significantly affect household or female empowerment outcomes in a sample of 275 borrowers and existing microenterprises. Setboonsarng and Parpiev (2008) use a similar technique to show how significant income generating activities, such as agricultural production, are associated with the provision of microloans. Ghalib, Malki and Imai (2011) show that microcredit has a statistically significant positive impact on the economic wellbeing of households in rural Punjab.

\footnotetext{
${ }^{5}$ Pakistan Microfinance Network, Microwatch, issue 22, 2011.

${ }^{6}$ This includes academic research by independent researchers, not official reports from microfinance providers or funding agencies.
} 
Evidence on the impact of microfinance on women has been mixed. As yet, no study has used robust experimental techniques to measure the direct impact of microfinance on household and business outcomes for women borrowers, nor looked at the long-term impact of microfinance or the sustainability of any change in outcomes.

\section{Literature Review}

The development potential of microfinance has recently been challenged by empirical studies that show limited improvements in household and business outcomes. This section provides an overview of the literature on the role and impact of access to finance, technical knowledge and the household and society in facilitating or constraining microenterprise by women in developing countries.

\subsection{Access to Finance}

The literature provides some direction for thinking about the likely impact of borrowed funds on women who do not run an existing business. However, most studies focus on the growth of existing businesses rather than the creation of new ones. Measuring the impact of a group lending program in Hyderabad, India, Duflo et al. (2013) find that, 15-18 months later, the profits of pre-existing businesses had increased. Although access to finance had helped a small number of women start their own enterprise, it was not significantly effective in helping them escape poverty. Similar results are found for Mexico (Angelucci, Karlan \& Zinman, 2015), rural Mongolia (Attanasio et al., 2015), Morocco (Crepon et al., 2015), Ethiopia (Tarozzi, Desai \& Johnson, 2015) and Bosnia and Herzegovina (Augsburg et al., 2015).

Banerjee et al. (2015) outline a series of randomized trials conducted across a total sample of more than 10,000 individuals in six countries (Ethiopia, Ghana, Honduras, India, Pakistan and Peru). The program in question offered financial grants as well as training and support in the form of frequent coaching visits by field officers. The results indicate no impact on household or business expenditure or on women's empowerment within the household 24-36 months later, but they do show an increase in total household assets and consumption and more time spent on productive activities. Fafchamps et al. (2014), on the other hand, find that cash grants have an insignificant impact on both male- and female-run enterprises, casting doubt on the role of finance alone in enhancing business growth. Their results imply that the mechanism through which assistance is 
provided to women matters: cash assistance alone may not be enough to benefit an enterprise and/or sustain profit improvements.

These mixed results might be explained by the nature of microfinance loans - small loans at high interest rates may be inherently illsuited or insufficient to promote long-term microenterprise growth or creation. Bandiera et al. (2013) find that, for the ultra-poor in rural Bangladesh, sizeable asset loans (worth approximately US\$140) helped increase earnings by almost 40 percent, even after the assistance was withdrawn. They also find a substantial shift among women from agricultural labor to running a business. Beaman et al. (2014) believe that the success of large borrowers may have to do with self-selection. Using a randomized controlled trial to evaluate the impact of agricultural loans, they find that farmers who experience the highest returns are more likely to borrow in the first place.

Other studies find that business outcomes improve when borrowers are given a grace period before repayment commences (Field et al., 2013). In addition, a highly elastic demand may crowd out viable borrowers (Karlan \& Zinman, 2013), while equity-like loans - as opposed to joint-liability loans - are more efficient in encouraging enterprise among women micro-entrepreneurs (Fischer, 2011).

\subsection{Training and Technical Knowledge}

The results cited above reflect that loans in themselves may not be enough to prompt the efficient and productive use of funds and need to be complemented with skills or training (Blattman et al., 2015). Valdivia (2015) shows that business outcomes improve for recipients of technical training in Peru. McKenzie and Woodruff (2014) conclude that, while training may help start an enterprise, it does not necessarily ensure business growth. Their evidence implies that training hastens the entry of businesses that were going to enter the market regardless; it does not boost the entry of businesses that would not have otherwise been set up.

\subsection{Microenterprise Preferences: The Role of the Individual, Household and Society}

A detailed analysis of the characteristics of borrowers who succeed in improving business outcomes under the traditional microfinance structure provides further insights into why enterprises may be constrained. For example, a low level of initial assets has been shown to 
inhibit self-control (Bernheim, Ray \& Yeltekin, 2013) and may limit the productive use of resources. We can also expect investment in a business with delayed or riskier returns to be lower among risk-averse or presentbiased entrepreneurs. The lower (if not insignificant) growth of female-run enterprises could also be a result of the household dynamics under which women have to operate. For instance, de Mel, McKenzie and Woodruff $(2009,2012)$ find that the gap between male-run and female-run business outcomes in Sri Lanka is lower for women from more 'cooperative' households where they are more involved in household decision making.

Examining an intervention involving business loans and intensive training for micro-borrowers in Pakistan, Giné and Mansuri (2011) find no improvement in business knowledge among female entrepreneurs. They argue that it is not necessarily the ablest women who self-select into enterprise. Rather, given the social and cultural constraints to their mobility, female entrepreneurs may see enterprise purely as a source of 'appropriately' earned income that does not require them to leave home. As a result, they may not be motivated enough to improve business outcomes. Similarly, if women fear the 'capture' of their earnings by a spouse or other household members, this may remove their motivation to increase their income beyond subsistence level.

Empowerment is broadly defined as the process by which individuals become able to make strategic life-choices (Kabeer, 1999). Ngo and Wahhaj (2012) show that the empowerment-enhancing potential of a loan to a woman can depend on whether her spouse has an incentive to capture her resources for personal or household use. Capture is less likely if the woman carries out an autonomous activity and her spouse does not have an alternative activity that provides comparable returns. Similarly, the relative economic contribution of men and women is positively correlated with their degree of influence over household decisions (Grasmuck \& Espinal, 2000). Insofar as this may have to do with the greater fungibility of cash, coupled with internal or external pressure to use those funds in a way that provides immediate benefit to household members (Fafchamps, Kebede \& Quisumbing, 2009; Jakiela \& Ozier, 2012), the impact of a loan on business is likely to be small and transitory.

It is only recently that experimental techniques have been used to obtain objective measures of empowerment levels. Indeed, studies based on field experiments highlight the motivation for disempowered household members to 'hide' loans or funds available to them to prevent capture. In a study on the Philippines, Ashraf (2009) gave married couples 
the option to deposit an experimental endowment in either a joint account with their spouse or in a private account, but at a cost. She found that both men and women are more likely to deposit money in private accounts if their spouse controls the household finances; this is true even if they have to give up a portion of the endowment to do so. In a subsequent study, Ashraf, Karlan and Yin (2010) find that women who are able to open private savings accounts experience an increase in decision-making power in the household.

Mani (2011) and Fiala (2015) show that spouses in India and Uganda, respectively, are willing to sacrifice the efficient investment option in an experiment to determine which option provides greater control over returns. Further, as Ashraf (2009) also shows, this is less likely to happen when men have positive 'interaction' with their wives outside the experiment. In a similar experiment for Senegal, Boltz, Marazyan and Villar (2015) find that individuals who choose to 'hide' their income do so in trying to escape pressure to share from household members.7 Other studies have looked at the concept of capture in the context of patriarchal and nuclear families (see Kazianga \& Wahhaj, 2015), bargaining power (see Murillo, 2015), asymmetric information on household finances (see Hoel, 2015) and information asymmetries imposed by geographical distance in migrant families (see Ambler, 2015).

If the resources owned by the less empowered are likely to be captured, then providing loans may not be enough to create new enterprise or increase the welfare of the recipient. Given the social and cultural context, women are likely to be the more disadvantaged members of the household (Carlsson et al., 2012) and may not be able to exercise control over funds. In his seminal paper, Chiappori (1988) rejects the notion of a Pareto-efficient household utility model: households cannot be characterized by a single utility function (see also Chiappori, 1997). Theoretically, a married woman's relative weight in household decisions is larger if (i) she comes from a wealthy family before marriage, (ii) the customary divorce laws are favorable to women (Dercon \& Krishnan, 2000), (iii) the distribution of income or household-sharing rule is skewed toward women (Browning, Chiappori \& Lechene, 2006; Browning,

\footnotetext{
${ }^{7}$ Almas et al. (2015), Castilla and Walker (2013), Castilla (2014) and Schaner (2015) conduct similar field experiments and find that spouses who lack information on each other's financial resources and come from noncooperative households where they do not have a say in decision making are more likely to hide their earnings or investments. In a study on Ethiopia, Kebede et al. (2011) find that individuals are likely to share less of their endowment with a spouse if the size of the endowment remains hidden from the latter.
} 
Chiappori \& Lewbel, 2006) or (iv) there is symmetric information among household members (Chen, 2013).

The 'unitary' model of household utility has been rejected by several empirical studies in different contexts. ${ }^{8}$ Studies have also shown that the welfare impact of financial and information interventions differs by the gender of the decision maker (Duflo, 2003; Duflo \& Udry, 2004; Bobonis, 2009). In addition, there may be psychological costs of hiding resources. Ashraf, Field and Lee (2014), for instance, find that women who hide contraceptive decisions from their spouse suffer from a lower subjective wellbeing.

Finally, loan recipients may be subject to certain social or familial standards or norms of behavior. These standards may be accepted norms of behavior enforced by peer pressure or fear of condemnation or through internalized shame or guilt over a broken social rule. When these standards are (implicitly) enforced, they can limit the discretion a female borrower has over use of the loan. Recognizing the role of social pressures, Krupka and Weber (2013) have designed a novel game intended to elicit an individual's perception of social norms. Their results imply that individuals care about more than monetary incentives when undertaking entrepreneurial activities.

\section{Conclusion and Suggestions for Future Research}

One cannot look at the constraints to setting up an enterprise without looking at the environment in which entrepreneurs operate. In the case of women, there may be other constraints aside from a difficult business environment. Cultural and social norms play an important role in determining the decision to set up and/or operate a business, sometimes superseding the (female) entrepreneur's own decision. Access to finance is a partial answer to encouraging enterprise, but any investigation of the constraints women might face in setting up or sustaining an enterprise is incomplete without considering self-discipline and family as well as social pressures.

Empirical experiments have fast become the gold standard in academic research. Quantitative research is far from perfect, often providing an incomplete picture of the impact. Such studies may be able to measure the quantitative change in outcomes, but without uncovering the process through which this change occurs. However, empirical research

\footnotetext{
${ }^{8}$ See, for instance, Iversen et al. (2011); Munro, Bateman and McNally (2008); Robinson (2012).
} 
has the advantage of being able to measure the causal impact of alleviating a constraint objectively and quantitatively, e.g., providing loans to set up a business. With a well-designed intervention, researchers may be able to measure the expected average or representative impact of the intervention.

Measuring an individual's preference for hiding his or her earnings and family or social pressure to share these is problematic if one relies on self-reported data through survey questions. Individuals may react very differently when responding to a survey question about a hypothetical situation and when reacting in a real-life situation. Recently, there has been a move toward lab experiments to uncover behavioral tendencies. While these originated in labs in the developing world, they have shifted to simple pen-and-paper exercises where individual decisions are tied to monetary incentives. These lab-in-the-field experiments are meant to mimic real life, using hypothetical situations in which decisions can have real-life monetary consequences.

Lab-in-the-field games have the added advantage of creating a within-subject panel dataset with multiple decisions by the same individual; this allows one to control for individual-level unobservables. Further, these games can be used to "force choices in starkly different options" in a contrived yet familiar context, allowing multiple tests of theoretical predictions (Hoel, 2015). While this is an improvement on survey questions, we may still find that individuals behave differently in real life. In gender dynamics, interactions outside the lab may also influence behavior within the experiment. However, the literature provides some guidance on how to capture these dynamics using cleverly designed experiments.

In a currently ongoing study, we use a randomized controlled trial involving microenterprise loans for women in Punjab (Pakistan) to measure the impact of access to finance on business creation in this sample ${ }^{9}$. In addition, we use incentivized survey questions and lab-in-thefield experiments to identify social and household norms regarding the 'acceptable' level of autonomy available to female borrowers in deciding how to use their funds. At the time of loan disbursement, these women were not different in terms of measurable variables such as income, education, marital status, household assets and expenditure. A year later, there is evidence to suggest that household and social dynamics may have influenced which women used the loan to set up an enterprise. For

\footnotetext{
${ }^{9}$ This study is a joint work between Azam Chaudhary, Mahreen Mahmud and Farah Said.
} 
instance, compared to the views held by housewives, self-employed women view society to be more favorable towards female entreprenuers. This may reflect the pressures women consider when deciding whether to set up their own business.

To my knowledge, such experiments have not been conducted using a sample of microenterprise loan applicants. This fills a gap in the literature by directly testing for the role of constraints - credit, social norms and household dynamics - in determining enterprise, household and individual-level outcomes. This study also addresses a specific gap in the literature on Pakistan by using a randomized controlled trial to study the impact of a microfinance product on the borrower's household and individual outcomes. The results from this and similar studies could help design pro-poor policies in Pakistan and other developing countries. They will also be directly relevant to microfinance organizations operating in Pakistan, often with a focus on women's empowerment through access to finance, and to policymakers who have recently shown considerable interest in promoting enterprise among women and youth. 


\section{References}

Almas, I., Armand, A., Attanasio, O., \& Carneiro, P. (2015). Measuring and changing control: Womens empowerment and targeted transfers (No. 21717). Cambridge, MA: National Bureau of Economic Research.

Ambler, K. (2015). Don't tell on me: Experimental evidence of asymmetric information in transnational households. Journal of Development Economics, 113, 52-69.

Angelucci, M., Karlan, D., \& Zinman, J. (2015). Microcredit impacts: Evidence from a randomized microcredit program placement experiment by Compartamos Banco. American Economic Journal: Applied Economics, 7(1), 151-182.

Ashraf, N. (2009). Spousal control and intra-household decision making: An experimental study in the Philippines. American Economic Review, 99(4), 1245-1277.

Ashraf, N., Field, E., \& Lee, J. (2014). Household bargaining and excess fertility: An experimental study in Zambia. American Economic Review, 104(7), 2210-2237.

Ashraf, N., Karlan, D., \& Yin, W. (2010). Female empowerment: Impact of a commitment savings product in the Philippines. World Development, 38(3), 333-344.

Asim, S. (2009). Evaluating the impact of microcredit on women's empowerment in Pakistan (Working Paper No. 3). Lahore: CREB.

Attanasio, O., Augsburg, B., De Haas, R., ... Harmgart, H. (2015). The impacts of microfinance: Evidence from joint-liability lending in Mongolia. American Economic Journal: Applied Economics, 7(1), 90122.

Augsburg, B., De Haas, R., Harmgart, H., \& Meghir, C. (2015). The impacts of microcredit: Evidence from Bosnia and Herzegovina. American Economic Journal: Applied Economics, 7(1), 183-203.

Bandiera, O., Burgess, R., Das, N., ... Sulaiman, M. (2013). Can basic entrepreneurship transform the economic lives of the poor? (EOPP Discussion Paper No. 43). London: London School of Economics and Political Science. 
Banerjee, A., Duflo, E., Goldberg, N., ... Udry, C. (2015). A multifaceted program causes lasting progress for the very poor: Evidence from six countries. Science, 348(6236), 772-789.

Baumol, W. J. (1968). Entrepreneurship in economic theory. American Economic Review, 58(2), 64-71.

Beaman, L., Karlan, D., Thuysbaert, B., ... Cohen, A. W. (2014). Selfselection into credit markets: Evidence from agriculture in Mali (Working Paper No. 20387). Cambridge, MA: National Bureau of Economic Research.

Bernheim, B. D., Ray, D., \& Yeltekin, Ş. (2013). Poverty and self-control (No. 18742). Cambridge, MA: National Bureau of Economic Research.

Blattman, C., Green, E. P., Jamison, J. C., ... Annan, J. (2015). The returns to microenterprise support among the ultra-poor: A field experiment in post-war Uganda (Working Paper No. 21310). Cambridge, MA: National Bureau of Economic Research.

Bobonis, G. J. (2009). Is the allocation of resources within the household efficient? New evidence from a randomized experiment. Journal of Political Economy, 117(3), 453-503.

Boltz, M., Marazyan, K., \& Villar, P. (2015). Income hiding and informal redistribution: A lab-in-the-field experiment in Senegal. Unpublished manuscript, Paris School of Economics.

Browning, M., Chiappori, P.-A., \& Lechene, V. (2006). Distributional effects in household models: Separate spheres and income pooling. Unpublished manuscript. Retrieved from http://www.columbia.edu/ p pc2167/mbpacv191106.pdf

Browning, M., Chiappori, P.-A., \& Lewbel, A. (2013). Estimating consumption economies of scale, adult equivalence scales and household bargaining power. Review of Economic Studies, 80(4), 1267-1303.

Carlsson, F., He, H., Martinsson, P., ... Sutter, M. (2012). Household decision making in rural China: Using experiments to estimate the influences of spouses. Journal of Economic Behavior and Organization, 84(2), 525-536. 
Castilla, C. (2014). What's yours is mine, and what's mine is mine: Bargaining power and income concealing between spouses in India. Unpublished manuscript. Retrieved from http://sites.bu.edu/neudc/files/2014/10/paper_159.pdf

Castilla, C., \& Walker, T. (2013). Is ignorance bliss? The effect of asymmetric information between spouses on intrahousehold allocation. American Economic Review, 103(3), 263-268.

Chen, J. J. (2013). Identifying noncooperative behavior among spouses: Child outcomes in migrant-sending households. Journal of Development Economics, 100(1), 1-18.

Chiappori, P.-A. (1988). Nash-bargained households decisions: A comment. International Economic Review, 29(4), 791-796.

Chiappori, P.-A. (1997). Introducing household production in collective models of labor supply. Journal of Political Economy, 105(1), 191209.

Crépon, B., Devoto, F., Duflo, E., \& Parienté, W. (2015). Estimating the impact of microcredit on those who take it up: Evidence from a randomized experiment in Morocco. American Economic Journal: Applied Economics, 7(1), 123-150.

de Mel, S., McKenzie, D., \& Woodruff, C. (2009). Are women more creditconstrained? Experimental evidence on gender and microenterprise returns. American Economic Journal: Applied Economics, 1(3), 1-32.

de Mel, S., McKenzie, D., \& Woodruff, C. (2012). One-time transfers of cash or capital have long-lasting effects on microenterprises in Sri Lanka. Science, 335(6071), 962-966.

Dercon, S., \& Krishnan, P. (2000). In sickness and in health: Risk sharing within households in rural Ethiopia. Journal of Political Economy, 108(4), 688-727.

Duflo, E. (2003). Grandmothers and granddaughters: Old-age pensions and intrahousehold allocation in South Africa. World Bank Economic Review, 17, 1-25. 
Duflo, E., Banerjee, A., Glennerster, R., \& Kinnan, C. G. (2013). The miracle of microfinance? Evidence from a randomized evaluation (No. 18950). Cambridge, MA: National Bureau of Economic Research.

Duflo, E., \& Udry, C. (2004). Intrahousehold resource allocation in Cote D'Ivoire: Social norms, separate accounts and consumption choices (Working Paper No. 10498). Cambridge, MA: National Bureau of Economic Research.

Economist Intelligence Unit. (2012). Global microscope on the microfinance business environment 2012. London: Author.

Fafchamps, M., Kebede, B., \& Quisumbing, A. R. (2009). Intrahousehold welfare in rural Ethiopia. Oxford Bulletin of Economics and Statistics, 71(4), 567-599.

Fafchamps, M., McKenzie, D., Quinn, S., \& Woodruff, C. (2014).

Microenterprise growth and the flypaper effect: Evidence from a randomized experiment in Ghana. Journal of Development Economics, $106,211-226$.

Fiala, N. (2015). Business is tough, but family is worse: The role of family constraints on microenterprise development in Uganda. Unpublished manuscript, University of Connecticut, Storrs, CT.

Field, E., Pande, R., Papp, J., \& Rigol, N. (2013). Does the classic microfinance model discourage entrepreneurship among the poor? Experimental evidence from India. American Economic Review, 103(6), 2196-2226.

Fischer, G. (2011). Contract structure, risk sharing and investment choice (EOPP Discussion Paper No. 23). London: London School of Economics and Political Science.

Ghalib, K., Malki, I., \& Imai, K. S. (2011). The impact of microfinance and its role in easing poverty of rural households: Estimations from Pakistan (Discussion Paper No. 2011-28). Kobe: Kobe University.

Giné, X., \& Mansuri, G. (2011). Money or ideas? A field experiment on constraints to entrepreneurship in rural Pakistan. Unpublished manuscript, World Bank, Washington, DC. 
Grasmuck, S., \& Espinal, R. (2000). Market success or female autonomy? Income, ideology and empowerment among micro-entrepreneurs in the Dominican Republic. Gender and Society, 14(2), 231-255.

Hoel, J. B. (2015). Heterogeneous households: A within-subject test of asymmetric information between spouses in Kenya. Journal of Economic Behavior and Organization, 118, 123-135.

Iversen, V., Jackson, C., Kebede, B., ... Verschoor, A. (2011). Do spouses realize cooperative gains? Experimental evidence from rural Uganda. World Development, 39(4), 569-578.

Jakiela, P., \& Ozier, O. (2012). Does Africa need a rotten kin theorem? Experimental evidence from village economies (Policy Research Working Paper No. 6085). Washington, DC: World Bank.

Kabeer, N. (1999). Resources, agency, achievements: Reflections on the measurement of women's empowerment. Development and Change, 30(3), 435-464.

Karlan, D., \& Zinman, J. (2013). Long-run price elasticities of demand for credit: Evidence from a countrywide field experiment in Mexico (Working Paper No. 19106). Cambridge, MA: National Bureau of Economic Research.

Kazianga, H., \& Wahhaj, Z. (2015, July). Norms of allocation within nuclear and extended-family households. Paper presented at the AAEA and WAEA Joint Annual Meeting, San Francisco, CA.

Kebede, B., Tarazona, M., Munro, A., \& Verschoor, A. (2011). Intrahousehold efficiency: An experimental study from Ethiopia (Working Paper No. 1). Oxford: Centre for the Study of African Economies.

Knight, F. H. (1921). Risk, uncertainty and profit. Boston, MA: Houghton Mifflin.

Krupka, E. L., \& Weber, R. A. (2013). Identifying social norms using coordination games: Why does dictator game sharing vary? Journal of the European Economic Association, 11(3), 495-524.

Mani, A. (2011). Mine, yours or ours? The efficiency of household investment decisions: An experimental approach (Working Paper No. 64). Warwick: University of Warwick. 
McKenzie, D., \& Woodruff, C. (2014). What are we learning from business training and entrepreneurship evaluations around the developing world? World Bank Research Observer, 29(1), 48-82.

Munro, A., Bateman, I., \& McNally, T. (2008). The family under the microscope: An experiment testing economic models of household choice. Unpublished manuscript. Retrieved from http:// papers.ssrn.com/sol3/papers.cfm?abstract_id=1138969

Murillo, A. S. (2015). Do you really know the salary of your spouse? Unpublished manuscript. Retrieved from https://editorialexpress.com/cgibin/conference/download.cgi?db_name=NEUDC2015\&paper_id $=172$

Ngo, T. M.-P., \& Wahhaj, Z. (2012). Microfinance and gender empowerment. Journal of Development Economics, 99(1), 1-12.

Pakistan Bureau of Statistics. (2015). Labor Force Survey 2013-14. Retrieved from

http://www.pbs.gov.pk/sites/default/files//Labour\%20Force/ publications/lfs2013-

14/Annual\%20Report\%20of\%20LFS\%202013-14\%20Final.pdf

Robinson, J. (2012). Limited insurance within the household: Evidence from a field experiment in Kenya. American Economic Journal: Applied Economics, 4(4), 140-164.

Safavian, M., \& Haq, A. (2013). Are Pakistan's women entrepreneurs being served by the microfinance sector? Washington, DC: World Bank.

Schaner, S. (2015). Do opposites detract? Intrahousehold preference heterogeneity and inefficient strategic savings. American Economic Journal: Applied Economics, 7(2), 135-174.

Schumpeter, J. (1942). Capitalism, socialism and democracy. New York: Harper \& Row.

Setboonsarng, S., \& Parpiev, Z. (2008). Microfinance and the Millennium Development Goals in Pakistan: Impact assessment using propensity score matching (Discussion Paper No. 104). Tokyo: Asian Development Bank Institute. 
Tarozzi, A., Desai, J., \& Johnson, K. (2015). The impacts of microcredit: Evidence from Ethiopia. American Economic Journal: Applied Economics, 7(1), 54-89.

Valdivia, M. (2015). Business training plus for female entrepreneurship? Short and medium-term experimental evidence from Peru. Journal of Development Economics, 113, 33-51.

Villasenor, J. D., Darrell M. W., \& Lewis, R. L. (2016). The 2016 Brookings financial and digital inclusion project report: Advancing equitable financial ecosystems. Washington: Center for Technology Innovation at Brookings.

Yoong, J., Rabinovich, L., \& Diepeveen, S. (2012). The impact of economic resource transfers to women versus men: A systematic review. London: University of London, Institute of Education. 